\title{
Prospecting Biomarkers for Diagnostic and Therapeutic Approaches in Pythiosis
}

\author{
Jéssica Luana Chechi ${ }^{1} * \mathbb{D}^{-}$, Tiwa Rotchanapreeda ${ }^{2}$, Giselle Souza da Paz ${ }^{3}{ }^{\mathbb{D}}$, Ana Carolina Prado ${ }^{1}$, \\ Alana Lucena Oliveira ${ }^{3}$, José Cavalcante Souza Vieira ${ }^{1}$, Marília Afonso Rabelo Buzalaf ${ }^{4} \mathbb{D}$, \\ Anderson Messias Rodrigues ${ }^{5}\left({ }^{\circ}\right.$, Lucilene Delazari dos Santos ${ }^{6,7}{ }^{\circ}$, Theerapong Krajaejun ${ }^{2}(\mathbb{C}$ \\ and Sandra de Moraes Gimenes Bosco $1,3, * \mathbb{0}$
}

check for

updates

Citation: Chechi, J.L.;

Rotchanapreeda, T.; da Paz, G.S.;

Prado, A.C.; Oliveira, A.L.; Vieira,

J.C.S.; Buzalaf, M.A.R.; Rodrigues,

A.M.; Santos, L.D.d.; Krajaejun, T.;

et al. Prospecting Biomarkers for

Diagnostic and Therapeutic

Approaches in Pythiosis. J. Fungi

2021, 7, 423. https://doi.org/

$10.3390 /$ jof7060423

Academic Editor: Andrew M. Borman

Received: 16 February 2021

Accepted: 5 May 2021

Published: 28 May 2021

Publisher's Note: MDPI stays neutral with regard to jurisdictional claims in published maps and institutional affiliations.

Copyright: () 2021 by the authors Licensee MDPI, Basel, Switzerland. This article is an open access article distributed under the terms and conditions of the Creative Commons Attribution (CC BY) license (https:// creativecommons.org/licenses/by/ $4.0 /)$.
1 Department of Chemical and Biological Sciences, Institute of Biosciences, São Paulo State University (UNESP), Botucatu 18618-689, Brazil; anapr1102@gmail.com (A.C.P.); cavalcante.vieira@unesp.br (J.C.S.V.)

2 Department of Pathology, Faculty of Medicine Ramathibodi Hospital, Mahidol University, Bangkok 10400, Thailand; ai-kaze@hotmail.com (T.R.); mr_en@hotmail.com (T.K.)

3 Faculty of Veterinary Medicine and Animal Science (FMVZ), São Paulo State University (UNESP), Botucatu 18618-681, Brazil; giselle.spaz@yahoo.com.br (G.S.d.P.); alanalucenaoliveira@gmail.com (A.L.O.)

4 Department of Biological Sciences, Bauru School of Dentistry, University of São Paulo (USP), Bauru 17012-901, Brazil; mbuzalaf@fob.usp.br

5 Department of Microbiology, Immunology and Parasitology, Cell Biology Division, Federal University of São Paulo (UNIFESP), São Paulo 04023-062, Brazil; amrodrigues.amr@gmail.com

6 Center for the Study of Venoms and Venomous Animals (CEVAP), São Paulo State University (UNESP), Botucatu 18610-307, Brazil; lucilene.delazari@unesp.br

7 Graduate Program in Tropical Diseases, Botucatu Medical School (FMB), São Paulo State University (UNESP), Botucatu 18618-687, Brazil

* Correspondence: jlchechi@gmail.com (J.L.C.); sandra.bosco@unesp.br (S.d.M.G.B.)

Abstract: Pythiosis, whose etiological agent is the oomycete Pythium insidiosum, is a life-threatening disease that occurs mainly in tropical and subtropical countries, affecting several animal species. It is frequently found in horses in Brazil and humans in Thailand. The disease is difficult to diagnose because the pathogen's hyphae are often misdiagnosed as mucoromycete fungi in histological sections. Additionally, there is no specific antigen to use for rapid diagnosis, the availability of which could improve the prognosis in different animal species. In this scenario, we investigated which $P$. insidiosum antigens are recognized by circulating antibodies in horses and humans with pythiosis from Brazil and Thailand, respectively, using 2D immunoblotting followed by mass spectrometry for the identification of antigens. We identified 23 protein spots, 14 recognized by pooled serum from horses and humans. Seven antigens were commonly recognized by both species, such as the heat-shock cognate $70 \mathrm{KDa}$ protein, the heat-shock $70 \mathrm{KDa}$ protein, glucan 1,3-beta-glucosidase, fructose-bisphosphate aldolase, serine/threonine-protein phosphatase, aconitate hydratase, and 14-3-3 protein epsilon. These results demonstrate that there are common antigens recognized by the immune responses of horses and humans, and these antigens may be studied as biomarkers for improving diagnosis and treatment.

Keywords: Pythium insidiosum; pythiosis; antigens; diagnosis; therapy; immunoproteomics

\section{Introduction}

Pythiosis, whose etiological agent is the oomycete Pythium insidiosum, is an emerging and life-threatening disease that occurs most frequently in tropical and subtropical countries, affecting several animal species, especially horses, dogs, and humans [1-3]. This pathogen is a colonizing agent of aquatic plants in which asexual reproduction occurs via the production of sporangia. When mature, these rupture and release zoospores, the infective form of $P$. insidiosum. Zoospores move in the water until they find another plant 
or animal with injured tissue in which they encyst and emit a germ tube, creating a new hypha that induces the appearance of lesions $[3,4]$.

Due to the recurrent presence in regions with water accumulation, horses are the most affected by the disease, with skin lesions being the most frequent clinical manifestation. Hyphae are observed in the lesions, covered by necrotic cells that form white-yellowish masses called "kunkers". The intestinal form may also be present, and the animals affected have colic episodes due to obstruction of the intestinal lumen $[5,6]$.

In humans, the disease is common in Southeast Asia, mainly in Thailand, and can also be found in the Americas and Oceania. Cutaneous and subcutaneous lesions usually take the form of granulomatous lesions or eye lesions, such as keratitis and corneal ulcers [7]. The clinical manifestation of the disease in humans can also be systemic or vascular. These manifestations are considered the most serious because they result in occlusion of the vessels [8]. In Brazil, a single report of human pythiosis was described in São Paulo, whose source of infection was due to fishing activity $[9,10]$.

The disease is difficult to diagnose since the pathogen's hyphae are often confused with mucoromycete fungi in histological sections, and diagnostic methods used in the identification of $P$. insidiosum are time-consuming [11-15]. The diagnosis of pythiosis is traditionally based on the association of clinical manifestations with culture identification [16-18], serodiagnostic tests [11,15,19-26], and molecular assays [13,18,27-29]. The treatment of pythiosis is also difficult because the pathogen does not respond satisfactorily to the available antifungals, and it is necessary to perform surgical procedures, often extensively, when possible $[1,3]$.

Studies involving $P$. insidiosum antigens from human pythiosis have identified a $74 \mathrm{KDa}$ protein, which has been considered as an immunodominant antigen [30]. This protein was identified as B-glucanase, showing homology with a similar protein in Phytophthora infestans, an oomycete phylogenetically close to P. insidiosum [31]. In the P. insidiosum secretome, the elicitin antigen was analyzed in immunohistochemical tests showing $100 \%$ sensitivity in the histological sections of pythiosis tested [14,32]. The immuneproteome of P. insidiosum revealed antigens of different molecular weights (around $34 \mathrm{KDa}$ and $50-55 \mathrm{KDa}$ ) that are recognized by immunoglobulins present in the serum from infected dogs, rabbits, horses, and cattle. However, serum immunoreactive proteins have not been identified [33].

The use of immunoproteomic approaches can help identify a large set of pythiosisassociated antigens that elicit immune responses during the interplay between host and pathogen. Thus, this study targeted $P$. insidiosum antigens specifically recognized by antibodies in equine and human pythiosis with the potential for use as putative biomarkers in the diagnosis and treatment of the disease. Immunoproteomic analysis was performed to select the immunoreactive molecules in the serum of these infected species.

\section{Materials and Methods}

\subsection{Pythium Insidiosum Strain and Culture Conditions}

The Pythium insidiosum strain used in this study, named "Eq10", was isolated from a male horse with pythiosis from São Paulo, Brazil. This strain was identified down to the species level via DNA sequencing of ITS (Internal Transcribed Spacer) region of ribosomal DNA with the panfungal primers ITS4-ITS5 [34]. The mycelial fragments of the isolate were transferred to Erlenmeyers, containing $100 \mathrm{~mL}$ of Sabouraud Dextrose Broth (Difco, Detroit, MI, USA), and incubated under shaking (ES-20 Orbital Shaker-Incubator) at $120 \mathrm{rpm}$ at $37^{\circ} \mathrm{C}$ for five days. After that period, Sabouraud broth was removed, and the mycelial mass was washed three times with deionized sterile water.

\subsection{Protein Sample Extraction}

Pythium insidiosum proteins were obtained as described by Rodrigues et al., with modifications [35]. The mycelial mass was frozen in liquid nitrogen and disrupted by grinding with a pestle until a fine powder was obtained. The powder mycelium was 
submitted to the Precellys instrument ( 2 cycles of 20 s; Bertin instruments, Montigny-leBretonneux, France) in $1 \mathrm{~mL}$ of Tris-Ca ${ }^{2+}$ buffer $\left(20 \mathrm{mM}\right.$ Tris- $\mathrm{HCl} \mathrm{pH} \mathrm{8.8,} 2 \mathrm{mM} \mathrm{CaCl}_{2}$ ) containing a commercial cocktail of protease inhibitors (1:100; GE Healthcare, Chicago, IL, USA), RNase, and DNase enzymes (1:100; GE Healthcare); and glass beads (Sigma, St. Louis, MO, USA, $425-600 \mu \mathrm{m})$. Afterwards, the cell debris and glass beads were removed via centrifugation at $14,000 \times g$ for $10 \mathrm{~min}$ at $4{ }^{\circ} \mathrm{C}$, and dithiothreitol $(20 \mathrm{mM}$; Sigma, St. Louis, $\mathrm{MO}, \mathrm{USA}$ ) was added to the supernatant. The protein concentration was determined by the Bradford (Bio-Rad, Hercules, CA, USA) method [36], and the sample was kept at $-80{ }^{\circ} \mathrm{C}$.

\subsection{Serum Samples from Infected Horses and Humans}

Sera from horses with definitive diagnoses of pythiosis (via P. insidiosum isolation in culture) were collected during animal care at the Veterinary Hospital from the School of Veterinary Medicine and Animal Sciences, UNESP, Botucatu, São Paulo, Brazil, in 2008 and 2018 and stored at $-20{ }^{\circ} \mathrm{C}$ until use. The samples $(n=22)$ were pooled to increase the recognition of seroreactive spots and avoid host-specific effects. Normal horse serum samples $(n=5)$ from animals without evidence of other mycotic diseases were used as a control.

Immunoblot was also performed with pooled serum from humans $(n=10)$ with pythiosis from Thailand. These patients had the diagnosis confirmed by culture identification, molecular analysis, and serological tests [37-39] at the Department of Pathology, Faculty of Medicine, Ramathibodi Hospital, Mahidol University, Bangkok, Thailand. All serum samples were stored at $-20^{\circ} \mathrm{C}$ until use. Serum from healthy Thai humans, who came to the Blood Bank Division, Ramathibodi Hospital, were used as control.

The use of clinical samples has been approved by the Committee for Research, Faculty of Medicine, Ramathibodi Hospital, Mahidol University, Bangkok, Thailand (assigned number: MURA2017/379), and by the Ethics Committee on the Use of Animals from the Institute of Biosciences, UNESP, Botucatu/SP, Brazil (CEUA 4345220321).

\subsection{Two-Dimensional Gel Electrophoresis}

Proteins $(150 \mu \mathrm{g})$ were precipitated using acetone at $80 \%(1: 4)$, with incubation for $90 \mathrm{~min}$ at $4{ }^{\circ} \mathrm{C}$ and then centrifugation at $14,000 \times \mathrm{g}$ for $10 \mathrm{~min}$ at $4{ }^{\circ} \mathrm{C}$. The proteins were diluted with commercial rehydration solution, DeStreak (GE Healthcare, Little Chalfont, $\mathrm{UK})$, and $1 \%(v / v)$ isoelectric focusing (IEF) buffer (GE Healthcare, Chicago, IL, USA), $\mathrm{pH} 4-7$, to a final volume of $125 \mu \mathrm{L}$. Isoelectric focusing was performed using the Ettan IPGphor III system (GE Healthcare, Chicago, IL, USA). Immobilized pH gradient (IPG) strips ( $\mathrm{pH} 4-7,7 \mathrm{~cm}$ ) were rehydrated overnight and subsequently focused at $300 \mathrm{~V}$ for $1 \mathrm{~h}, 1000 \mathrm{~V}$ for $1 \mathrm{~h}, 5000 \mathrm{~V}$ for $1 \mathrm{~h}$, and $5000 \mathrm{~V}$ for $40 \mathrm{~min}$. Finally, the voltage was set to $5000 \mathrm{~V}$ until $7000 \mathrm{Vhr}$, all performed at $20{ }^{\circ} \mathrm{C}$. The IPG strips were equilibrated in $19 \mathrm{mM}$ dithiothreitol (DDT) in equilibration buffer (50 mM Tris-HCl pH 8.8, $6 \mathrm{M}$ urea, 20\% glycerol, $2 \%(w / v)$ SDS, and $0.01 \%(w / v)$ bromophenol blue) for $15 \mathrm{~min}$, followed of $0.2 \mathrm{M}$ iodoacetamide in equilibrium buffer for $15 \mathrm{~min}$. The second dimension was performed on $12.5 \%(w / v)$ polyacrylamide gels, sealed with $0.5 \%$ agarose and proteins separated using Mini-Protean Tetra cell (Bio-Rad, Hercules, CA, USA; $150 \mathrm{~V}$ for $15 \mathrm{~min}$ and $200 \mathrm{~V}$ for $100 \mathrm{~min}$ ). After separation, gels were stained with Coomassie Brilliant Blue R-250 (50\% $(v / v)$ ethanol, $5 \%(v / v)$ acetic acid) for $60 \mathrm{~min}$ [40], or directly transferred in the case of immunoblot analysis. The gels were scanned using the ImageScanner III (GE Healthcare Life Sciences, Uppsala, Sweden) calibrated in transmission mode.

\subsection{D Immunoblotting of P. insidiosum Proteins}

Pythium insidiosum proteins were resolved by $2 \mathrm{D}$ gel electrophoresis followed by immunoblotting to evaluate seroreactive spots for serum from horses and humans with pythiosis. The proteins were transferred onto a $0.2 \mu \mathrm{m}$ nitrocellulose membrane using the Trans-Blot Turbo Transfer Pack (Bio-Rad, Hercules, CA, USA) at $25 \mathrm{~V}$ for $15 \mathrm{~min}$ using the 
Trans-Blot ${ }^{\circledR}$ Turbo ${ }^{\mathrm{TM}}$ Blotting System (Bio-Rad, Hercules, CA, USA). Electrotransference was evaluated via Ponceau'S (0.15\% Ponceau'S and $1 \%(v / v)$ acetic acid) staining.

The membranes were destained and then blocked overnight in TBST blocking buffer (20 mM Tris-HCl, $\mathrm{pH} 7.4 ; 137 \mathrm{mM} \mathrm{NaCl} ; 0.1 \%(v / v)$ Tween 20, supplemented with $5 \%(w / v)$ skim milk; pH 7.4) at $4{ }^{\circ} \mathrm{C}$ under constant shaking. To perform immunoblotting from the horse serum, the membranes were probed with primary antibody diluted to 1:100 (pooled serum from horses) for $4 \mathrm{~h}$ at $4{ }^{\circ} \mathrm{C}$ under constant shaking. Afterwards, the membranes were washed three times with washing buffer (TBS, pH 7.5; 0.05\% Tween 20) for $5 \mathrm{~min}$ and incubated with the secondary antibody anti-horse IgG (whole molecule)-Peroxidase, an antibody produced in rabbits (Sigma, ref. A6917, St. Louis, MO, USA), at a 1:1000 dilution for $2 \mathrm{~h}$ at room temperature. The membranes were washed with washing buffer, and labeling was conducted for chemiluminescent detection (Immobilon Classico Western HRP Substrate, Merck Millipore, Burlington, MA, USA) using the image analyzer Image Quant LAS 4000 (GE Healthcare Life Sciences). The immunoblotting of the Thai patient's serum was performed with some modifications. Membranes were probed with primary antibody diluted to 1:1000 (the pooled serum of human patients) for $2 \mathrm{~h}$ at room temperature under constant shaking. Afterwards, the membranes were washed three times with washing buffer (TBS, pH 7.5; 0.05\% Tween 20) for 5 min and incubated with secondary antibody goat anti-human immunoglobulin $\mathrm{G}$ conjugated with horseradish peroxidase (Bio-Rad, Hercules, CA, USA) at a 1:5000 dilution for $2 \mathrm{~h}$ at room temperature. Next, the membranes were washed with washing buffer, and labeling was conducted via chemiluminescence (Pierce ECL Western Blotting Substrate; Thermo Fisher, Waltham, MA USA) and image analyzer ChemiDoc ${ }^{\mathrm{TM}}$ MP Imaging System (Bio-Rad, Hercules, CA, USA) [30]. The gels and membranes images were analyzed by software Image Master 2D Platinum (7.0 version, GE Healthcare, Hercules, CA, USA).

\subsection{Trypsin Digestion and Mass Spectrometry}

The 2D immunoblot seroreactive proteins were manually excised, destained with 50\% $(v / v)$ ethanol and $2.5 \%(v / v)$ acetic acid solution, dehydrated with $100 \%(v / v)$ acetonitrile (gradient grade; Merck, Darmstadt, Germany) and $50 \mathrm{mM}$ ammonium bicarbonate (99.5\% purity; Sigma Chemical, Barcelona, Spain), and digested with trypsin (sequencing grade; Promega, Barcelona, Spain) [41].

The analysis of the triptych peptides by mass spectrometry was performed using Ultimate 3000 LC liquid nanochromatography equipment (Dionex, Germering, Germany) coupled with Q-Exactive mass-spectrometry equipment (Thermo Fisher Scientific, Bremen, Germany). The mobile phases used were (A) $0.1 \%(v / v)$ formic acid in LCMS water and (B) $0.1 \%(v / v)$ formic acid in $80 \%(v / v)$ acetonitrile. The peptides were loaded on a C18 pre-column, $30 \mu \mathrm{m} \times 5 \mathrm{~mm}$ (Code 164649, Thermo Fisher Scientific), and desalinated in an isocratic gradient of $4 \% \mathrm{~B}$ for $3 \mathrm{~min}$ at a flow of $300 \mathrm{~nL} / \mathrm{min}$. Then, the peptides were fractionated by a Reprosil-Pur C18-AQ analytical column, $3 \mu \mathrm{m}, 120 \AA \AA, 105 \mathrm{~mm}$, Code 1PCH7515-105H354-NV (PICOCHIP) using a linear gradient of $4-55 \%$ B for $30 \mathrm{~min}$, $55 \%$ at $90 \%$ B for $1 \mathrm{~min}$, maintained at $90 \%$ B for $5 \mathrm{~min}$ and rebalanced at $4 \%$ B for $20 \mathrm{~min}$ at a flow of $300 \mathrm{~nL} / \mathrm{min}$. Ionization was achieved using a Nanospray ion source (PICOCHIP). The mode of operation was positive ionization using the data-dependent acquisition (DDA) method. The MS spectra were acquired from $\mathrm{m} / z 200$ to $\mathrm{m} / z 2000$ at a resolution of 70,000 and with a $100 \mathrm{~ms}$ injection time. The fragmentation chamber was conditioned with collision energy between $29 \%$ and $35 \%$ with a resolution of $17,500,50 \mathrm{~ms}$ of injection time, $4.0 \mathrm{~m} / \mathrm{z}$ of isolation window, and dynamic exclusion of $10 \mathrm{~s}$. Spectrometry data were acquired using the Thermo Xcalibur software (version 4.0.27.19, Thermo Fisher Scientific Inc.).

\subsection{Bioinformatic Analysis}

Raw data from the mass spectrometry (RAW) were submitted to the PatternLab software (version 4.0.0.84) [42] for protein identification. The main parameters used were 
the SwissProt database (taxonomy Phytophthora infestans); trypsin enzyme; permission for 2 missing cleavages; the post-translational carbamidomethylation modification of cysteine residues; the variable post-translational modification oxidation of methionine residues; and tolerance errors of MS 40 ppm and MS/MS 0.0200 ppm. The maximum FDR (False Discovery Rate) was considered to be $\leq 1 \%$.

Comparative analyses of data were performed in the Venny 2.1 program [43-45]. The protein-protein interaction networks were constructed using the online STRING database [46] version 11.0. The STRING network analysis was performed with a medium confidence level (0.4) [47]. The in-silico SCRATCH protein prediction suite was used to investigate antigenic properties of seroreactive proteins [48] available online [49]. The amino acid sequences of the antigens analyzed in the SCRATCH protein prediction were searched with genome information using Pythium insidiosum strain Pi-S (accession number GCA_001029375.1) [50]. The analyzed parameters included the determination of putative epitopic regions in antigens by evaluating continuous B-cell epitopes using COBEpro [51], the secondary structure using SSpro and SSpro8 [52], and the protein antigenicity based on multiple representations of the primary sequence using the ANTIGENpro and SVMTriP software [53].

\section{Results}

\subsection{Pythium Insidiosum Protein Profile and Immunoreactive Proteins}

The protein profile, the spots' location, and the identification of proteins shown in our previous work [54] were consistent with the results obtained in the present study, thus demonstrating the robustness of our methodology. The protein profiles of the different $P$. insidiosum isolates studied are similar in terms of the number and molecular weight of bands and spots observed in the 1D and 2D-PAGE electrophoresis, respectively (Supplemental Figures S1 and S2). Therefore, we conducted the present work using the P. insidiosum strain "Eq-10".

The protein extraction protocol, Tris- $\mathrm{Ca}^{2+}$, was suitable for the study of P. insidiosum antigenic molecules, generating samples with a high quantity of proteins $(2.23 \mu \mathrm{g} / \mu \mathrm{L})$ that were not degraded (Figure 1). To evaluate the samples, $150 \mu \mathrm{g}$ of proteins were resolved by two-dimensional gel electrophoresis. Initially, IPG strips ranging from 3 to 10 were used. The gels obtained showed the low resolution of spots in the $\mathrm{pH}$ range from 3 to 10 and better separation of spots by the isoelectric point using strips with a $\mathrm{pH}$ range of 4-7 (Supplemental Figure S3). Thus, the 2D electrophoresis was conducted using an immobilized $\mathrm{pH}$ gradient of 4-7, obtaining better sample resolution and separation.

Two-dimensional-gel Western blotting analysis revealed a total of 23 immunoreactive spots that were immunoreactive to the pooled serum of horses and humans diagnosed with pythiosis (Figure 1). Spots with molecular weights (MWs) ranging from 28 to $88 \mathrm{KDa}$ and isoelectric points (pI) between 4.58 and 6.60 were detected via the horse sera (Figure 1A,B) and human sera (Figure $1 C, D)$. The control sera of horses and humans were not immunoreactive.

A total of sixteen individual proteins were successfully identified by mass spectrometry from 23 immunoreactive spots (Table 1 and Table S1). Ten spots $(1-5,9,14,17,18$, and 19; Figure 1) were immunoreactive for both horse and human serum. These were identified and corresponded to seven individual proteins listed in Table 2. 

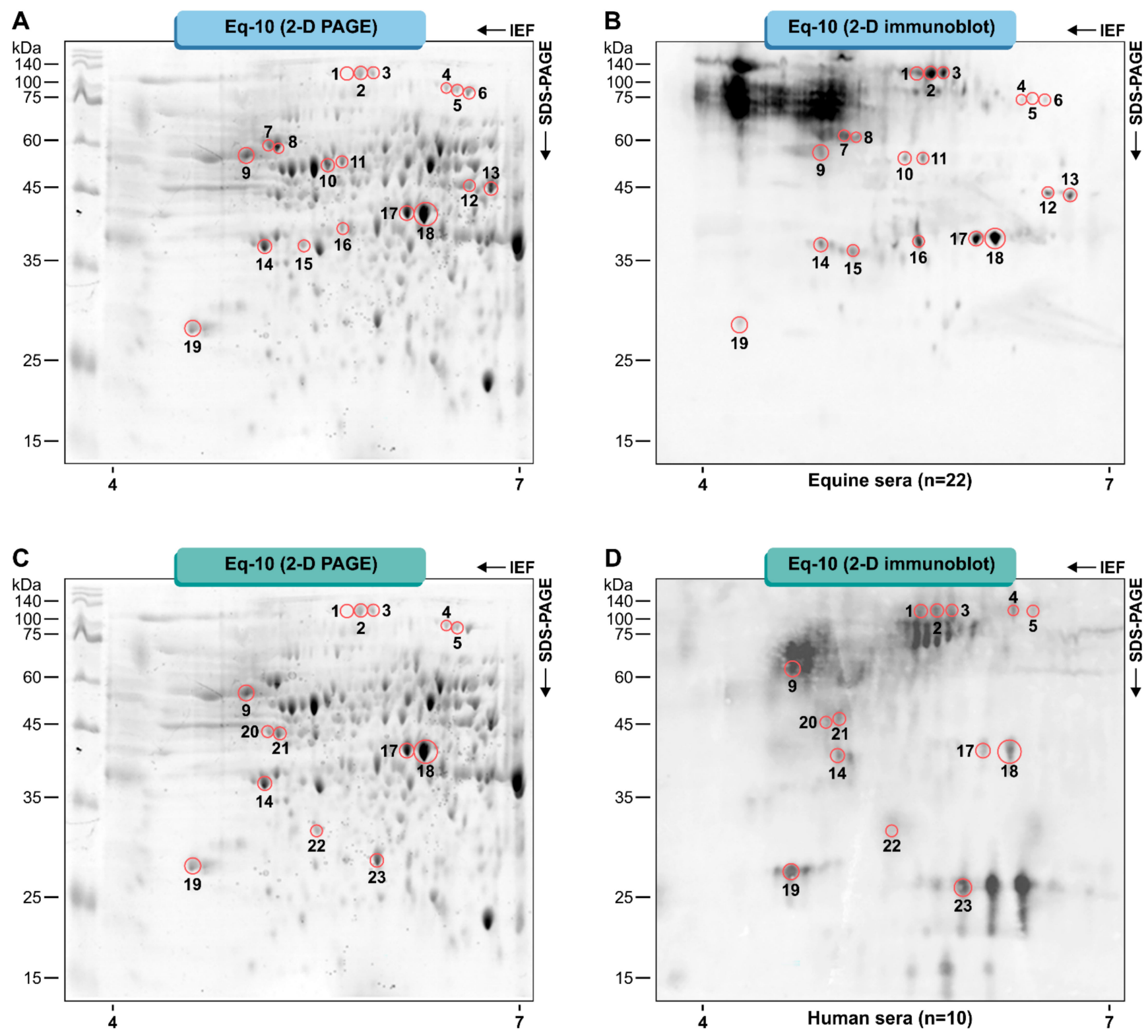

Figure 1. The 2D protein profile of the Eq-10 isolate of Pythium insidiosum $(\mathbf{A}, \mathbf{C})$. Identification of immunoreactive proteins from P. insidiosum by 2D Western blot analysis in pooled horse sera (B) and pooled human sera (D). The numbers of the spots refer to the identification used in Tables 1 and 2. The experiments were run in triplicate.

Table 1. Summary of immunoreactive proteins in Pythium insidiosum identified by mass spectrometry.

\begin{tabular}{|c|c|c|c|c|c|c|c|}
\hline Spot No & Protein Name & $\begin{array}{c}\text { Accession } \\
\text { No (Uniprot) }\end{array}$ & Gene & $\begin{array}{l}\text { Pred MW } \\
\text { (KDa) }\end{array}$ & pI & $\begin{array}{l}\text { Protein } \\
\text { Score }\end{array}$ & $\begin{array}{c}\text { Coverage } \\
(\%)\end{array}$ \\
\hline 1 & Heat shock cognate $70 \mathrm{kDa}$ protein & D0NHI7 & PITG_11913 & 86 & 5.54 & 66.239 & 16 \\
\hline \multirow[t]{2}{*}{2} & Heat shock cognate $70 \mathrm{kDa}$ protein & D0NHI7 & PITG_11913 & 86 & 5.65 & 54.232 & 14 \\
\hline & Glucan 1,3-beta-glucosidase & DONEL9 & PITG_10218 & 69 & 5.65 & 40.664 & 7 \\
\hline \multirow[t]{2}{*}{3} & Heat shock cognate $70 \mathrm{kDa}$ protein & D0NHI7 & PITG_11913 & 86 & 5.74 & 41.397 & 14 \\
\hline & Glucan 1,3-beta-glucosidase & D0NEL9 & PITG_10218 & 69 & 5.74 & 17.895 & 5 \\
\hline 4 & Aconitate hydratase & D0NY26 & PITG_18048 & 88 & 6.26 & 122.175 & 23 \\
\hline 5 & Aconitate hydratase & D0NY26 & PITG_18048 & 88 & 6.35 & 191.649 & 27 \\
\hline 6 & Aconitate hydratase & D0NY26 & PITG_18048 & 88 & 6.47 & 164.533 & 26 \\
\hline 7 & Chaperonin CPN60-1 & D0NHM8 & PITG_11966 & 63 & 5.07 & 293.798 & 34 \\
\hline 8 & Chaperonin CPN60-1 & D0NHM8 & PITG_11966 & 63 & 5.12 & 359.499 & 35 \\
\hline 9 & Heat shock $70 \mathrm{kDa}$ protein & D0NSJ5 & PITG_15786 & 68 & 4.90 & 12.61 & 8 \\
\hline
\end{tabular}


Table 1. Cont.

\begin{tabular}{|c|c|c|c|c|c|c|c|}
\hline Spot No & Protein Name & $\begin{array}{c}\text { Accession } \\
\text { No (Uniprot) }\end{array}$ & Gene & $\begin{array}{l}\text { Pred MW } \\
\text { (KDa) }\end{array}$ & pI & $\begin{array}{l}\text { Protein } \\
\text { Score }\end{array}$ & $\begin{array}{c}\text { Coverage } \\
(\%)\end{array}$ \\
\hline 10 & $\begin{array}{l}\text { 6-phosphogluconate } \\
\text { dehydrogenase }\end{array}$ & D0NE49 & PITG_10032 & 53 & 5.46 & 82.972 & 28 \\
\hline 11 & Vacuolar proton pump subunit B & D0N6F5 & PITG_06118 & 57 & 5.55 & 248.97 & 50 \\
\hline 12 & Isocitrate dehydrogenase [NADP] & D0N755 & PITG_07056 & 48 & 6.47 & 188.754 & 43 \\
\hline 13 & Isocitrate dehydrogenase [NADP] & D0N755 & PITG_07056 & 48 & 6.60 & 183.697 & 44 \\
\hline 14 & $\begin{array}{l}\text { Serine/threonine-protein } \\
\text { phosphatase }\end{array}$ & D0MXY7 & PITG_03574 & 35 & 5.06 & 10.346 & 23 \\
\hline 15 & $40 \mathrm{~S}$ ribosomal protein SA & D0MUE8 & PITG_01922 & 31 & 5.22 & 72.538 & 26 \\
\hline 16 & Transaldolase & D0N3B2 & PITG_05636 & 37 & 5.74 & 24.121 & 16 \\
\hline 17 & Fructose-bisphosphate aldolase & D0MX78 & PITG_02785 & 43 & 6.00 & 25.961 & 4 \\
\hline 18 & Fructose-bisphosphate aldolase & D0MX78 & PITG_02785 & 43 & 6.14 & 246.075 & 26 \\
\hline 19 & 14-3-3 protein epsilon & DONYS2 & PITG_19017 & 28 & 4.58 & 425.094 & 82 \\
\hline 20 & Arginase & D0N266 & PITG_04851 & 38 & 5.00 & 59.674 & 13 \\
\hline 21 & Arginase & D0N266 & PITG_04851 & 38 & 5.10 & 115.704 & 17 \\
\hline 22 & $\begin{array}{c}\text { Glycerol-3-phosphate } \\
\text { dehydrogenase [NAD }(+)]\end{array}$ & D0N0G8 & PITG_04065 & 38 & 5.34 & 46.334 & 20 \\
\hline 23 & Triosephosphate isomerase & D0MZB6 & PITG_03078 & 25 & 5.81 & 52.947 & 14 \\
\hline
\end{tabular}

Table 2. Immunoreactive protein matching between pooled horse and human serum. Predicted antigenic propensity scores based on SCRATCH and biological process from the Uniprot database are given.

\begin{tabular}{cccc}
\hline Spot No & Protein & SCRATCH Score & Biological Process \\
\hline 2 and 3 & Exo-1,3-ß-glucanase & 0.935295 & carbohydrate metabolic process \\
1,2 and 3 & HSC 70 & 0.899345 & stress response \\
4 and 5 & Aconitate hydratase & 0.895298 & tricarboxylic acid cycle \\
19 & $14-3-3$ & 0.892100 & signaling protein ligands \\
9 & HSP 70 & 0.877913 & protein folding and stress response \\
17 and 18 & Fructose-bisphosphate aldolase & 0.738101 & glycolytic process \\
\hline
\end{tabular}

\subsection{Protein Identification}

The proteins resulting from the immunoblot of $P$. insidiosum with pooled horse and human serum were analyzed in the Venn diagram. Horse and human serum showed thirteen and ten proteins, respectively. Among these proteins, six (37.5\%) were exclusively from horses, three (18.8\%) from humans, and seven (43.8\%) were shared antigens.

Network interactions among the sixteen proteins identified (Table 1) highlight the seven immunoreactive proteins matching between pooled horse and human serum (Figure 2A). Among the proteins highlighted in Figure 2A, we observed direct interactions among Hsc 70 (PITG_11913), Hsp 70 (PITG_15786), and 14-3-3 (PITG_19017). Of the sixteen proteins found in this study, eight are related to the biosynthesis of secondary metabolites and metabolic pathways, seven proteins participate in the biosynthesis of antibiotics, and six act in the pathways of amino acid biosynthesis and carbon metabolism, among other functions described in the other proteins (Figure 2B). 
A
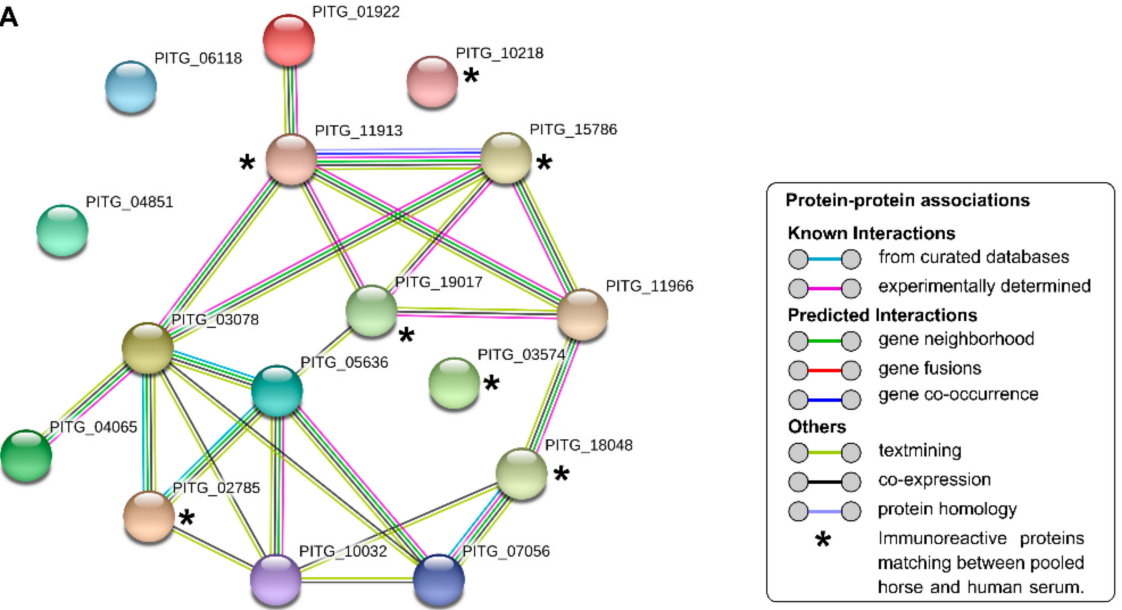

B
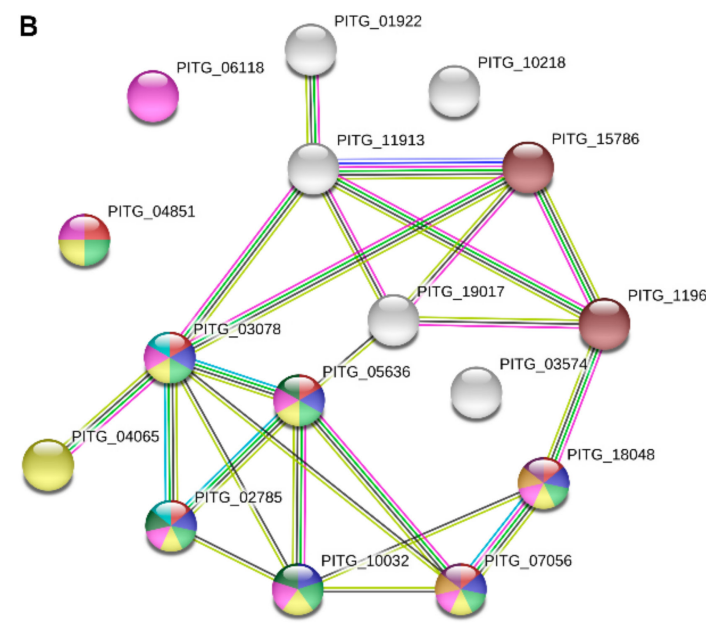

Functional enrichments in the network

Figure 2. STRING analysis of the Pythium insidiosum immunoproteome. (A) The STRING proteinprotein interaction network for the 16 immunogenic proteins in human and equine pythiosis. The proteins shared between the two immunoproteomes are marked with an asterisk. Colored lines between the proteins indicate the various types of interaction evidence. (B) Classification of proteins based on the KEGG pathways. The protein-protein interactions' enrichment $p$-value $=3.47 \times 10^{-6}$.

The predictions of the presence of B-cell epitopes showed a strong antigenicity propensity mainly in antigens Exo-1,3-ß3-glucanase (antigenicity propensity: 0.935295, Figure 3A), Heat-shock cognate $70 \mathrm{kDa}$ protein (antigenicity propensity: 0.899345, Figure 3B), Aconitate hydratase (antigenicity propensity: 0.895298, Figure 3C), 14-3-3 protein epsilon (antigenicity propensity: 0.892100 , Figure 3D), Heat-shock $70 \mathrm{kDa}$ protein (antigenicity propensity: 0.877913 , Figure 3E), and Fructose-bisphosphate aldolase (antigenicity propensity: 0.738101, Figure 3F) (Figure 3, Table 2). These high antigenicity propensity scores are remarkable when compared to those for classic antigenic proteins from pathogenic fungi, such as the 43 KDa glycoprotein (AAG36672) in Paracoccidioides brasiliensis (antigenicity propensity: 0.604208) and the $\mathrm{H}$-antigen (EGC41021) in Histoplasma capsulatum (antigenicity propensity: 0.777265). Serine/threonine-protein phosphatase (Phytophthora infestans) and anoctaminlike protein, corresponding protein in Pythium insidiosum, presented low antigenicity, with values of 0.345502 and 0.134275 , respectively. Therefore, we did not analyze the B-cell epitopes of these proteins. 
A

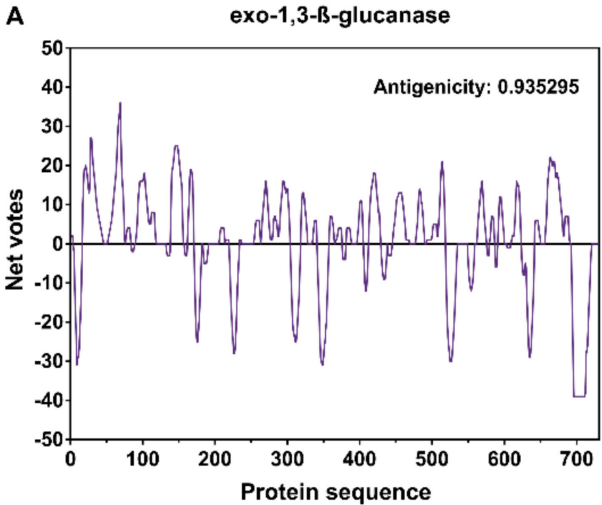

C

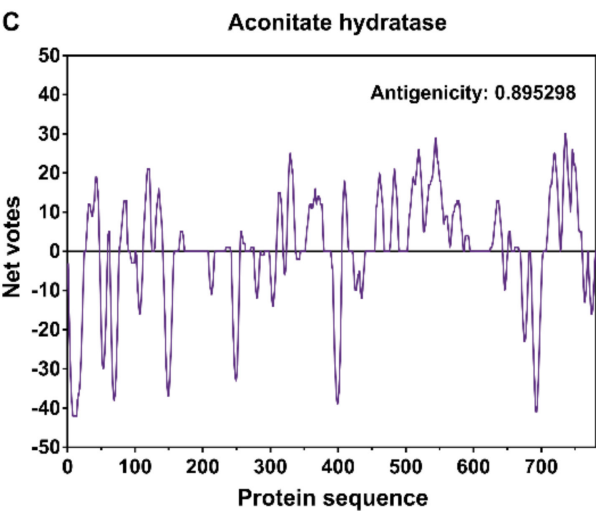

E

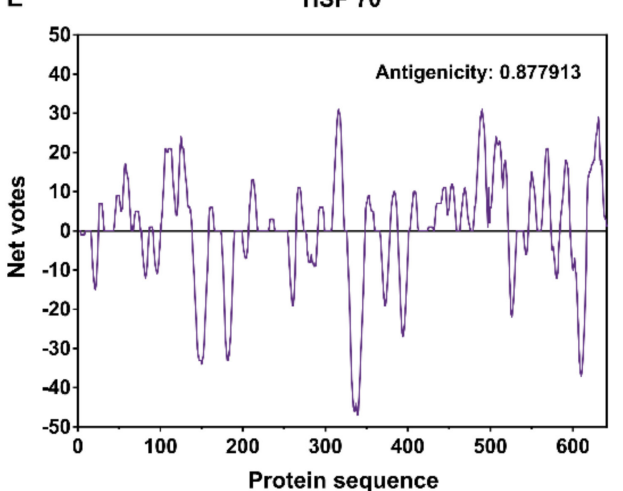

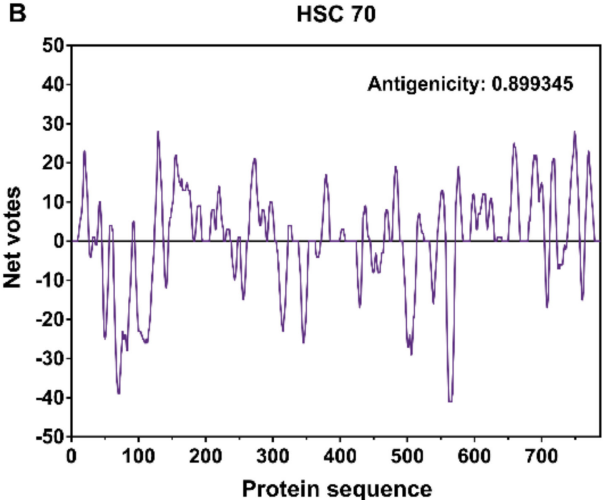

D
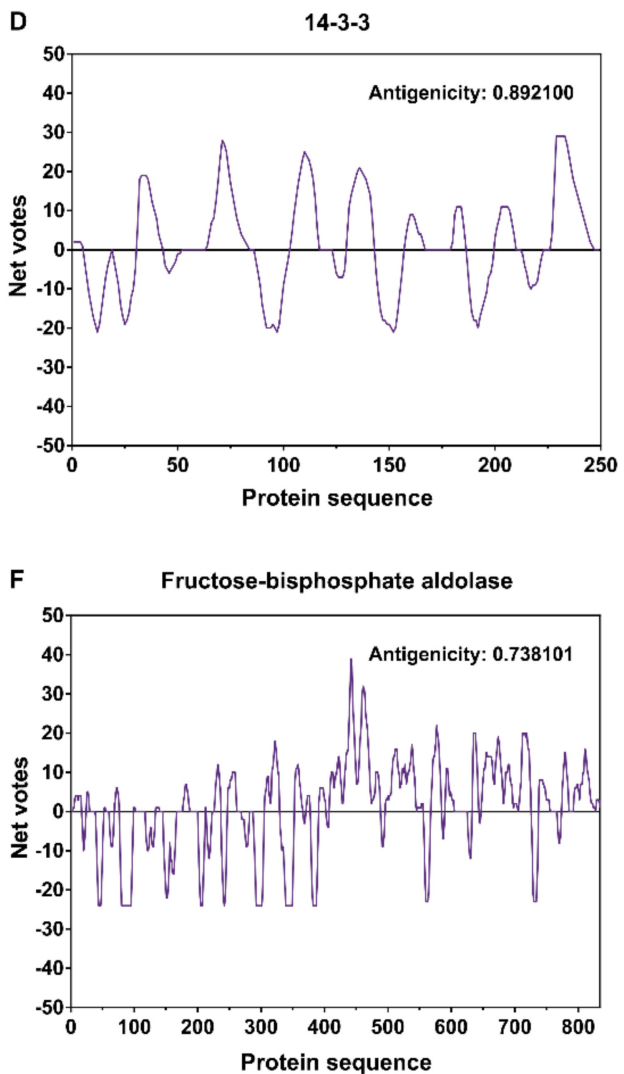

Figure 3. Prediction of the six antigens (A-F) of higher antigenic propensity scores. According to the algorithm COBEpro, the antigenic propensity scores are plotted against position along the amino acid sequence. The higher the antigenic propensity scores, the more likely there is to be antigenic activity for the respective region.

\section{Discussion}

Early diagnosis is essential for the successful treatment of pythiosis. The accurate diagnosis of pythiosis includes culture identification [16-18], which is time-consuming and may fail to grow the organism; molecular assays, based on PCR, require qualified personnel and specialized equipment [13,26-29]; serodiagnostic tests (e.g., immunodiffusion, enzymelinked immunosorbent assay [ELISA], immunochromatographic tests, immunoblot, and hemagglutination) are used for the detection of circulating antibodies; however, such tests produce false-negative results $[11,15,19-26]$. The present study adopted an immunoproteomic approach to compare antibody responses in horse and human serum to identify new antigens in pythiosis. 
The proteins extracted from P. insidiosum were fractionated by 2D PAGE and evaluated using Western blotting with pooled horse and human serum infected with pythiosis. Twenty-three immunoreactive spots were detected, and we identified sixteen individual proteins since the same protein was identified in two or more spots. The presence of the same protein in multiple spots can be observed due to the existence of natural isoforms, post-translational modifications, or differences in sample preparation [55].

Among the seven matching spots, the protein identification revealed heat-shock cognate $70 \mathrm{KDa}$ protein (Hsc 70), heat-shock 70 KDa protein (Hsp 70), glucan 1,3-betaglucosidase, fructose-bisphosphate aldolase, aconitate hydratase, and serine/threonineprotein phosphatase,14-3-3 protein epsilon. Heat-shock cognate $70 \mathrm{KDa}$ protein was detected in three spots $(1,2$, and 3$)$, and this protein belongs to the heat-shock protein 70 family [56,57], along with heat-shock $70 \mathrm{KDa}$ protein (spot 9). Hsp 70 and Hsc 70 are chaperones found in all organisms, from bacteria to humans, in the cell membrane, cytoplasm, nucleus, endoplasmic reticulum, and mitochondria, and play a critical role in various biological processes involving both systemic and cellular stress related to changes in temperature [58,59]. In Saccharomyces cerevisiae, a mutation in the gene Y7 caused temperature sensitivity during its growth. When analyzing the mutant yeast suppressor genes, the SSB1 gene was observed, which codes for heat-shock cognate 70 KDa protein. The introduction of this gene in mutant cells supplied the defects in temperature sensitivity and facilitated the degradation of proteins encoded by genes with the mutation [60]. Hsp 70 protein from Paracoccidioides brasiliensis was recognized by serum from patients with paracoccidioidomycosis [61]. Studies related to Hsp 70 and Hsc 70 proteins and their functions in oomycetes are scarce. We believe that these proteins are essential in the pathogenicity of $P$. insidiosum since the pathogen is found in the environment, and when it invades a host tissue, it needs to adapt to the higher temperature, promoting the repair and modeling of proteins fundamental to its growth.

The glucan 1,3-beta-glucosidase protein was identified in spots 2 and 3. Although this enzyme is not the most abundant protein in both spots, heat-shock cognate $70 \mathrm{KDa}$ protein appears as the first identification with the highest score. However, this enzyme has been previously found in isolates of P. insidiosum in Brazil [54] and is also described as being immunodominant in studies conducted with serum from Thai patients with pythiosis [30,31]. Phylogenetic analysis with the exo1 gene, which codes for exo-1,3-ß-glucanase, grouped this gene close to other oomycetes and far from true fungi. The authors highlight this enzyme as a target for developing vaccines and drugs against the pathogen [62]. A study carried out with the pathogenic fungi Histoplasma capsulatum identified two proteins, endo and exo-13-1,3-glucanase, highly active in yeasts under infection conditions, while in the mycelial form (environmental form), these proteins are minimally expressed. These proteins were related to the pathogenicity of $H$. capsulatum $[63,64]$. Glucanase enzyme, endo-1,3(4)-beta-glucanase, was also found as an antigen in the secretome of Paracoccidioides spp. (P. americana, P. brasiliensis, and P. restrepiensis) yeast forms [65]. The ß-glucans are the main structural components of fungal cell walls, combined with other molecules that provide strength and rigidity $[66,67]$. Many fungi produce exocellular enzymes that degrade $B$-glucans, the $\beta$-glucanases ( $\$-1,3$ and $B-1,6$-glucanases) $[68,69]$. The glucan 1,3-beta-glucosidase identified in the present study is essential in the development of P. insidiosum because they play a fundamental role in the morpho-physiological processes of the cell wall, thus favoring the growth of hyphae.

The mass spectrometry and bioinformatics of spots 17 and 18 resulted in the identification of the fructose-1,6-bisphosphate aldolase ( $\mathrm{Fba}$ ) protein with a molecular mass of $43 \mathrm{KDa}$ and isoelectric points of 6.00 and 6.14, respectively. Fba proteins are enzymes used in glycolysis and gluconeogenesis and are classified into class I and class II [70-72]. Class I enzymes are present in plants, animals, algae, and prokaryotes. Class II, on the other hand, requires a metallic ion $\left(\mathrm{Zn}^{2+}\right.$ or $\left.\mathrm{Fe}^{2+}\right)$ in the catalytic cycle. Class II is absent in animals and plants, but it is essential to protozoa, microalgae, bacteria, and fungi, favoring studies with this enzyme as targets for new drugs [73,74]. This enzyme was highlighted in 
a recent study as an antigen in human paracoccidioidomycosis due to P. brasiliensis s. str. and P. lutzii [75]. Moreover, proteomic data show that P. lutzii fructose-1,6-bisphosphate aldolase interacts with macrophage proteins. Among the proteins identified, two were identified as serine proteinase (also found in this study, spot 14, Figure 1) and Fba, both expressed on the pathogen's surface during interaction with macrophages in the infectious process [76]. Fba was one of the Candida albicans proteins selected by peptide epitope search algorithms for developing a vaccine for candidiasis and showed the best results in reducing the renal fungal load [77,78]. In pathogenic fungi Cryptococcus neoformans [79] and Paracoccidioides lutzii [80], Fba binds to host molecules and performs an adhesion function, in addition to the glycolytic activity of the molecules. In this sense, we believe that the Fba protein found in our study may be involved in the interaction with host cells in the adhesion process, participating in the virulence of $P$. insidiosum.

Serine/threonine-protein phosphatase (spot 14) identified in the present study is an essential mediator of fungal proliferation and development, as well as infection-related morphogenesis and transduction. These proteins have phosphorylation functions and are essential to fundamental processes of fungi, such as cell cycle and transcription [81]. A study with Saccharomyces cerevisiae showed that the deletion of the SIT4 gene, which encodes the serine/threonine-protein phosphatase, increases the yeast's sensitivity to azoles, cycloheximide, daunorubicin, rhodamine B, and rhodamine 6G, suggesting a new therapeutic approach [82]. The deletion of the gene that codes for this same protein was also analyzed in C. albicans [83] and Aspergillus fumigatus [84], resulting in more sensitivity to oxidative stress of immune cells of the host [85]. This is an important discovery since, to avoid the host's innate immune system, pathogens need to survive oxidative conditions in neutrophils and macrophages [86].

Another detected antigen was the aconitate hydratase or aconitase (spots 4 and 5, Figure 1, Table 1). Aconitase plays a role in the Krebs cycle, catalyzing the conversion of citric acid to isocitric acid, resulting in molecules that produce energy and essential precursors for carbohydrates and amino acids [87]. In addition to its role in the Krebs cycle, this enzyme functions as an iron regulatory protein, controlling the ferritin and transferrin receptor's expression in mammalian cells [88]. In S. cerevisiae, aconitase was characterized as a conjugated protein containing an iron-sulfur prosthetic group, which acts on both substrates linking to the active site or in catalysis [89]. This enzyme's expression was evaluated in P. brasiliensis in the yeast and mycelial phases under cultivation in carbon sources or different levels of iron. Aconitase was more abundant in the yeast phase and when the fungus was incubated with a $C_{2}$ carbon source or high iron concentration [87]. An increase in the expression of aconitase over a high iron concentration was also observed in C. neoformans [90]. The possible role of aconitase in regulating the mechanisms of iron levels is supposed [87]. Many pathogens, both prokaryotes and eukaryotes, need iron in their vital metabolic process [91-93]. Genetic studies with P. insidiosum isolates from Thailand showed the gene that encodes for the enzyme ferrochelatase [94] which is necessary for heme biosynthesis, catalyzing the introduction of iron into porphyrin [92]. Information regarding the metabolism of iron in P. insidiosum is scarce; however, in Thailand, an important risk factor in human pythiosis is thalassemia. Patients presenting thalassemia show an overload of circulating iron that could benefit P. insidiosum. Anemic rabbits experimentally infected with $P$. insidiosum showed lesions larger than those in the control group [95].

Finally, spot 19 identified the 14-3-3 protein epsilon, which is highly conserved in eukaryotes and abundant in phospho-serine/threonine binding proteins [96-98]. The 14-3-3 epsilon plays important roles in the cell cycle, coordinating cell progression and acting on signal transformation networks through bonds with other proteins [97,99]; these bonds affect the conformation and function of target proteins [98]. In Paracoccidioides brasiliensis, the 14-3-3 protein (Pb14-3-3) is a critical antigen [75], which is highly expressed in virulent isolates and works as an adhesin [100]. The downregulation of Pb14-3-3 leads to morphological modifications, such as more elongated cells, an impairment in dimor- 
phism, decreased interaction with pneumocytes, and reduced bud number [101]. Still, in P. brasiliensis, Marcos et al. [102] observed that the downregulation of the 14-3-3 protein alters the pathogen's ability to cause host cell apoptosis, which may be due to a consequence of the decreased secretion of Pb14-3-3 or the loss of putative adherence mediated by 14-3-3. In Pythium insidiosum, this protein may be related to the pathogen's virulence favoring the adhesion process, as mentioned in the literature.

The proteins described here showed immunoreactivity exclusively to equine and human sera with pythiosis. There was no immunoreactivity with sera from healthy humans and equines. These antigens have already been demonstrated to be crucial in the pathogenesis and virulence of several fungi, such as Histoplasma capsulatum [63,64], Paracoccidioides spp. [61,65,75,76,80,100,102], Aspergillus fumigatus [84], Saccharomyces cerevisiae [60,82,89], Cryptococcus neoformans [79,90], and Candida albicans [83]; as well as in studies involving the development of vaccines for Candida albicans [77,78] and Paracoccidioides spp. [103]. Among these proteins, we have fructose-bisphosphate aldolase and glucan 1,3-beta-glucosidase, which are not related to homolog proteins in the human host [104].

In the present study, we have identified and characterized antigens recognized by the serum of horses and humans with pythiosis. The antigens showed here are predicted to be potent immunogenic molecules based on the presence of B-cell epitopes. These proteins can be used as new biomarkers for the diagnosis of pythiosis and treatment of this important neglected disease.

\section{Conclusions}

A total of 23 immunoreactive spots were identified for the pooled horse serum from Brazil and human serum from Thailand. The spots were identified by mass spectrometry and bioinformatic analysis, resulting in the detection of 16 unique proteins. Seven matching antigens were discussed and related to their functions in different pathogenic fungi such as glucan 1,3-B-glucosidase, Hsc 70, Hsp 70, aconitate hydratase, serine/threonine-protein phosphatase, fructose-biphosphate aldolase, and 14-3-3 protein epsilon. The matching antigens found here may be promising for studying new methods for diagnosing and treating pythiosis.

Supplementary Materials: The following are available online at https:/ /www.mdpi.com/article/ 10.3390/jof7060423/s1, Figure S1: The protein profiles of the eight different Pythium insidiosum isolates show that are similar in terms of the number and molecular weight of bands observed in the unidimensional electrophoresis, Figure S2: Pythium insidiosum proteins fractionated using strips of $7 \mathrm{~cm}$ and $\mathrm{pH} 4-7$, in the first dimension, and $12.5 \%$ polyacrylamide gels in the second dimension. (A) Pythium insidiosum denominated "Eq-10". (B) “Eq-12". (C) “Eq-15". (D) “Eq-16". (E) “Eq-20”, Figure S3: Proteins $(150 \mu \mathrm{g})$ of Pythium insidiosum (Eq-10) resolved by two-dimensional gel electrophoresis. (A) IPG strips ranging from 3 to 10. (B) Separation of spots by isoelectric point using strips with a pH range of $4-7$.

Author Contributions: Conceptualization, J.L.C., M.A.R.B. and S.d.M.G.B.; data curation, J.L.C., J.C.S.V. and T.K; formal analysis, J.L.C., T.R., J.C.S.V. and S.d.M.G.B.; funding acquisition, J.L.C.; investigation, J.L.C., T.R., G.S.d.P., A.C.P., A.L.O., J.C.S.V., M.A.R.B., A.M.R., L.D.d.S., T.K. and S.d.M.G.B.; methodology, J.L.C., T.R., G.S.d.P., A.C.P., A.L.O., J.C.S.V., M.A.R.B., L.D.d.S., T.K. and S.d.M.G.B.; project administration, J.L.C. and S.d.M.G.B.; resources, J.L.C.; software, J.L.C., M.A.R.B., A.M.R. and L.D.d.S.; supervision, L.D.d.S., T.K. and S.d.M.G.B.; validation, L.D.d.S.; writingoriginal draft, J.L.C., A.M.R. and S.d.M.G.B.; writing-review \& editing, J.L.C., G.S.d.P., J.C.S.V., A.M.R., L.D.d.S., T.K. and S.d.M.G.B. All authors have read and agreed to the published version of the manuscript.

Funding: This research was funded by the Fundação de Amparo à Pesquisa do Estado de São Paulo-FAPESP (grants 2016/10804-8, 2018/08009-0 and 2019/08761-7) and the Coordenação de Aperfeiçoamento de Pessoal de Nível Superior-CAPES (code 001). 
Institutional Review Board Statement: The use of clinical samples has been approved by the Committee for Research, Faculty of Medicine, Ramathibodi Hospital, Mahidol University, Bangkok, Thailand (assigned number: MURA2017/379), and by the Ethics Committee on the Use of Animals from Institute of Biosciences, UNESP, Botucatu/SP, Brazil (CEUA 4345220321).

Informed Consent Statement: Informed consent was obtained from all subjects involved in the study.

Data Availability Statement: The mass spectrometry data this manuscript have been uploaded to the MassIVE Repository from Computer Science and Engineering University of California, San Diego (ftp:/ / massive.ucsd.edu/MSV000086565/, accessed on 1 February 2021) with the dataset identifier MSV000086565.

Acknowledgments: We are thankful to the Institute of Biotechnology (IBTEC), UNESP for the proteomics analyses conducted in this work, and the Center for the Study of Venoms and Venomous Animals-CEVAP (UNESP, Botucatu, SP, Brazil) for the support in the two-dimensional electrophoresis method. We also thank the Research Center, Mahidol University, Thailand, for their support with the assays conducted at this center. AMR is a fellow of FAPESP (2017/27265-5).

Conflicts of Interest: The authors declare no conflict of interest. The funders had no role in the design of the study; in the collection, analyses, or interpretation of data; in the writing of the manuscript, or in the decision to publish the results.

\section{References}

1. Gaastra, W.; Lipman, L.J.; De Cock, A.W.; Exel, T.K.; Pegge, R.B.; Scheurwater, J.; Vilela, R.; Mendoza, L. Pythium insidiosum: An overview. Vet. Microbiol. 2010, 146, 1-16. [CrossRef] [PubMed]

2. Krajaejun, T.; Sathapatayavongs, B.; Pracharktam, R.; Nitiyanant, P.; Leelachaikul, P.; Wanachiwanawin, W.; Chaiprasert, A.; Assanasen, P.; Saipetch, M.; Mootsikapun, P.; et al. Clinical and epidemiological analyses of human pythiosis in Thailand. Clin. Infect. Dis. 2006, 43, 569-576. [CrossRef]

3. Mendoza, L.; Ajello, L.; McGinnis, M.R. Infection caused by the Oomycetous pathogen Pythium insidiosum. J. Mycol. Med. 1996, 6, 151-164.

4. Mendoza, L.; Hernandez, F.; Ajello, L. Life Cycle of the Human and Animal Oomycete Pathogen Pythium insidiosum. J. Clin. Microbiol. 1993, 31, 2967-2973. [CrossRef] [PubMed]

5. $\quad$ Reis, J.L.; Carvalho, E.C.; Nogueira, R.H.; Lemos, L.S.; Mendoza, L. Disseminated pythiosis in three horses. Vet. Microbiol. 2003, 96, 289-295. [CrossRef]

6. Brown, C.C.; Roberts, E.D. Intestinal pythiosis in a horse. Aust. Vet. J. 1988, 65, 88-89. [CrossRef]

7. Krajaejun, T.; Pracharktam, R.; Wongwaisayawan, S.; Rochanawutinon, M.; Kunakorn, M.; Kunavisarut, S. Ocular pythiosis: Is it under-diagnosed? Am. J. Ophthalmol. 2004, 137, 370-372. [CrossRef]

8. Triscott, J.A.; Weedon, D.; Cabana, E. Human subcutaneous pythiosis. J. Cutan. Pathol. 1993, 20, 267-271. [CrossRef]

9. Bosco, S.M.G.; Bagagli, E.; Araújo, J.P., Jr.; Candeias, J.M.G.; Franco, M.F.; Marques, M.E.A.; Mendoza, L.; Camargo, R.P.; Alencar Marques, A.S. Human pythiosis Brazil. Emerg. Infect. Dis. 2005, 11, 715-717. [CrossRef]

10. Marques, A.S.; Bagagli, E.; Bosco, S.M.G.; Camargo, R.P.; Marques, M.E.A. Pythium insidiosum: Relato do primeiro caso de infecção humana no Brasil. An. Bras. Dermatol. 2006, 81, 483-485. [CrossRef]

11. Chareonsirisuthigul, T.; Khositnithikul, R.; Intaramat, A.; Inkomlue, R.; Sriwanichrak, K.; Piromsontikorn, S.; Kitiwanwanich, S.; Lowhnoo, T.; Yingyong, W.; Chaiprasert, A.; et al. Performance comparison of immunodiffusion, enzyme-linked immunosorbent assay, immunochromatography and hemagglutination for serodiagnosis of human pythiosis. Diagn. Microbiol. Infect. Dis. 2013, 76, 42-45. [CrossRef]

12. Intaramat, A.; Sornprachum, T.; Chantrathonkul, B.; Chaisuriya, P.; Lohnoo, T.; Yingyong, W.; Jongruja, N.; Kumsang, Y.; Sandee, A.; Chaiprasert, A.; et al. Protein A/G-based immunochromatographic test for serodiagnosis of pythiosis in human and animal subjects from Asia and Americas. Med. Mycol. 2016, 54, 641-647. [CrossRef] [PubMed]

13. Keeratijarut, A.; Lohnoo, T.; Yingyong, W.; Rujirawat, T.; Srichunrusami, C.; Onpeaw, P.; Chongtrakool, P.; Brandhorst, T.T.; Krajaejun, T. Detection of the oomycete Pythium insidiosum by real-time PCR targeting the gene coding for exo-1,3- $\beta$-glucanase. J. Med. Microbiol. 2015, 64, 971-977. [CrossRef] [PubMed]

14. Inkomlue, R.; Larbcharoensub, N.; Karnsombut, P.; Lerksuthirat, T.; Aroonroch, R.; Lohnoo, T.; Yingyong, W.; Santanirand, P.; Sansopha, L.; Krajaejun, T. Development of an anti-elicitin antibody-based immunohistochemical assay for diagnosis of pythiosis. J. Clin. Microbiol. 2016, 54, 43-48. [CrossRef]

15. Krajaejun, T.; Imkhieo, S.; Intaramat, A.; Ratanabanangkoon, K. Development of an immunochromatographic test for rapid serodiagnosis of human pythiosis. Clin. Vaccine Immunol. 2009, 16, 506-509. [CrossRef]

16. Chaiprasert, A.; Samerpitak, K.; Wanachiwanawin, W.; Thasnakorn, P. Induction of zoospore formation in Thai isolates of Pythium insidiosum. Mycoses 1990, 33, 317-323. [CrossRef]

17. Mendoza, L.; Prendas, J. A method to obtain rapid zoosporogenesis of Pythium insidiosum. Mycopathologia 1988, 104, 5962. [CrossRef] 
18. Grooters, A.M.; Whittington, A.; Lopez, M.K.; Boroughs, M.N.; Roy, A.F. Evaluation of microbial culture techniques for the isolation of Pythium insidiosum from equine tissues. J. Vet. Diagn. Investig. 2002, 14, 288-294. [CrossRef] [PubMed]

19. Krajaejun, T.; Kunakorn, M.; Niemhom, S.; Chongtrakool, P.; Pracharktam, R. Development and evaluation of an in-house enzyme-linked immunosorbent assay for early diagnosis and monitoring of human pythiosis. Clin. Diagn. Lab. Immunol. 2002, 9, 378-382. [CrossRef] [PubMed]

20. Mendoza, L.; Kaufman, L.; Mandy, W.; Glass, R. Serodiagnosis of human and animal pythiosis using an enzyme-linked immunosorbent assay. Clin. Diagn. Lab. Immunol. 1997, 4, 715-718. [CrossRef]

21. Jindayok, T.; Piromsontikorn, S.; Srimuang, S.; Khupulsup, K.; Krajaejun, T. Hemagglutination test for rapid serodiagnosis of human pythiosis. Clin. Vaccine Immunol. 2009, 16, 1047-1051. [CrossRef]

22. Mendoza, L.; Kaufman, L.; Standard, P.G. Immunodiffusion test for diagnosing and monitoring pythiosis in horses. J. Clin. Microbiol. 1986, 23, 813-816. [CrossRef]

23. Pracharktam, R.; Changtrakool, P.; Sathapatayavongs, B.; Jayanetra, P.; Ajello, L. Immunodiffusion test for diagnosis and monitoring of human pythiosis insidiosi. J. Clin. Microbiol. 1991, 29, 2661-2662. [CrossRef] [PubMed]

24. Keeratijarut, A.; Lohnoo, T.; Yingyong, W.; Sriwanichrak, K.; Krajaejun, T. A peptide ELISA to detect antibodies against Pythium insidiosum based on predicted antigenic determinants of exo-1,3-ß-glucanase. Southeast Asian J. Trop. Med. Public Health 2013, 44, 672-680. [PubMed]

25. Supabandhu, J.; Vanittanakom, P.; Laohapensang, K.; Vanittanakom, N. Application of immunoblot assay for rapid diagnosis of human pythiosis. J. Med. Assoc. Thail. 2009, 92, 1063-1071.

26. Vanittanakom, N.; Supabandhu, J.; Khamwan, C.; Praparattanapan, J.; Thirach, S.; Prasertwitayakij, N.; Louthrenoo, W.; Chiewchanvit, S.; Tananuvat, N. Identification of emerging human-pathogenic Pythium insidiosum by serological and molecular assay-based methods. J. Clin. Microbiol. 2004, 42, 3970-3974. [CrossRef] [PubMed]

27. Keeratijarut, A.; Lohnoo, T.; Yingyong, W.; Nampoon, U.; Lerksuthirat, T.; Onpaew, P.; Chongtrakool, P.; Krajaejun, T. PCR amplification of a putative gene for exo-1,3-ß-glucanase to identify the pathogenic oomycete Pythium insidiosum. Asian Biomed. 2014, 8, 637-644. [CrossRef]

28. Badenoch, P.R.; Coster, D.J.; Wetherall, B.L.; Brettig, H.T.; Rozenbilds, M.A.; Drenth, A.; Wagels, G. Pythium insidiosum keratitis confirmed by DNA sequence analysis. Br. J. Ophthalmol. 2001, 85, 502-503. [CrossRef] [PubMed]

29. Botton, S.A.; Pereira, D.I.; Costa, M.M.; Azevedo, M.I.; Argenta, J.S.; Jesus, F.P.K.; Alves, S.H.; Santurio, J.M. Identification of Pythium insidiosum by nested PCR in cutaneous lesions of Brazilian horses and rabbits. Curr. Microbiol. 2011, 62, 1225-1229. [CrossRef] [PubMed]

30. Krajaejun, T.; Kunakorn, M.; Pracharktam, R.; Chongtrakool, P.; Sathapatayavongs, B.; Chaiprasert, A.; Vanittanakom, N.; Chindamporn, A.; Mootsikapun, P. Identification of a Novel 74-Kilodalton Immunodominant Antigen of Pythium insidiosum Recognized by Sera from Human Patients with Pythiosis. J. Clin. Microbiol. 2006, 44, 1674-1680. [CrossRef]

31. Krajaejun, T.; Keeratijarut, A.; Sriwanichrak, K.; Lowhnoo, T.; Rujirawat, T.; Petchthong, T.; Yingyong, W.; Kalambaheti, T.; Smittipat, N.; Juthayothin, T.; et al. The 74-Kilodalton Immunodominant Antigen of the Pathogenic Oomycete Pythium insidiosum Is a Putative Exo-1,3-13-Glucanase. Clin. Vaccine Immunol. 2010, 17, 1203-1210. [CrossRef] [PubMed]

32. Lerksuthirat, T.; Lohnoo, T.; Inkomlue, R.; Rujirawat, T.; Yingyong, W.; Khositnithikul, R.; Phaonakrop, N.; Roytrakul, S.; Sullivan, T.D.; Krajaejun, T. The elicitin-like glycoprotein, ELI025, is secreted by the pathogenic oomycete Pythium insidiosum and evades host antibody responses. PLoS ONE 2015, 10, e0118547. [CrossRef]

33. Dal Ben, V.; Oliveira, R.S.; Borchardt, J.L.; Valente, J.S.S.; Brasil, C.L.; Zambrano, C.G.; Leite, F.P.L.; Botton, S.A.; Pereira, D.I.B. Protein profile of Brazilian Pythium insidiosum isolates. Med. Mycol. 2018, 56, 485-492. [CrossRef]

34. White, T.J.; Bruns, T.; Lee, S.; Taylor, J. Amplification and direct sequencing of fungal ribosomal RNA genes for phylogenetics. In PCR Protocols: A Guide to Methods and Applications; Innis, M., Gelfand, D., Shinsky, J., White, T., Eds.; Academic Press: New York, NY, USA, 1990; pp. 315-322.

35. Rodrigues, A.M.; Kubitschek-Barreira, P.H.; Fernandes, G.F.; de Almeida, S.R.; Lopes-Bezerra, L.M.; de Camargo, Z.P. Twodimensional gel electrophoresis data for proteomic profiling of Sporothrix yeast cells. Data Brief 2015, 2, 32-38. [CrossRef]

36. Bradford, M.M. Quantificação de microgramas de proteína utilizando o princípio da proteína de ligação de corante. Anal. Biochem. 1976, 72, 248-254. [CrossRef]

37. Chitasombat, M.N.; Jongkhajornpong, P.; Lekhanont, K.; Krajaejun, T. Recent update in diagnosis and treatment of human pythiosis. Peer] 2020, 8, e8555. [CrossRef] [PubMed]

38. Rujirawat, T.; Sridapan, T.; Lohnoo, T.; Yingyong, W.; Kumsang, Y.; Sae-Chew, P.; Tonpitak, W.; Krajaejun, T. Single nucleotide polymorphism-based multiplex PCR for identification and genotyping of the oomycete Pythium insidiosum from humans, animals and the environment. Infect. Genet. Evol. 2017, 54, 429-436. [CrossRef]

39. Lohnoo, T.; Jongruja, N.; Rujirawat, T.; Yingyon, W.; Lerksuthirat, T.; Nampoon, U.; Kumsang, Y.; Onpaew, P.; Chongtrakool, P.; Keeratijarut, A.; et al. Efficiency comparison of three methods for extracting genomic DNA of the pathogenic oomycete Pythium insidiosum. J. Med. Assoc. Thail. 2014, 97, 342-348.

40. Görg, A.; Obermaier, C.; Boguth, G.; Harder, A.; Scheibe, B.; Wildgruber, R.; Weiss, W. The current state of two-dimensional electrophoresis with immobilized $\mathrm{pH}$ gradients. Electrophoresis 2000, 21, 1037-1053. [CrossRef]

41. Shevchenko, A.; Wilm, M.; Vorm, O.; Mann, M. Mass spectrometric sequencing of proteins silver-stained polyacrylamide gels. Anal. Chem. 1996, 68, 850-858. [CrossRef] 
42. Carvalho, P.C.; Lima, D.B.; Leprevost, F.V.; Santos, M.D.M.; Fischer, J.S.G.; Aquino, P.F.; Moresco, J.J.; Yates, J.R., III; Barbosa, V.C. PatternLab for proteomics 4.0: A one-stop shop for analyzing shotgun proteomic data. Nat. Protoc. 2016, 11, 102-117. [CrossRef]

43. The UniProt Consortium. UniProt: The universal protein knowledgebase. Nucleic Acids Res. 2017, 45, 158-169. [CrossRef]

44. Oliveros, J.C. NoVENNY. An Interactive Tool for Comparing Lists with Venn Diagrams Title. Available online: http://bioinfogp. cnb.csic.es/tools/venny/index.html (accessed on 19 November 2019).

45. Venny 2.1. Available online: https:// bioinfogp.cnb.csic.es/tools/venny/ (accessed on 19 November 2019).

46. STRING. Available online: https://string-db.org (accessed on 22 November 2019).

47. Szklarczyk, D.; Franceschini, A.; Wyder, S.; Forslund, K.; Heller, D.; Huerta-Cepas, J.; Simonovic, M.; Roth, A.; Santos, A.; Tsafou, K.P.; et al. STRING v10: Protein-protein interaction networks, integrated over the tree of life. Nucleic Acids Res. 2015, 43, 447-452. [CrossRef] [PubMed]

48. Magnan, C.N.; Zeller, M.; Kayala, M.A.; Vigil, A.; Randall, A.; Felgner, P.L.; Baldi, P. High-throughput prediction of protein antigenicity using protein microarray data. Bioinformatics 2010, 26, 2936-2943. [CrossRef]

49. SCRATCH Protein Predictor. Available online: http:/ / scratch.proteomics.ics.uci.edu (accessed on 5 December 2019 ).

50. Rujirawat, T.; Patumcharoenpol, P.; Lohnoo, T.; Yingyong, W.; Lerksuthirat, T.; Tangphatsornruang, S.; Suriyaphol, P.; GrenvilleBriggs, L.J.; Garg, G.; Kittichotirat, W.; et al. Draft Genome Sequence of the Pathogenic Oomycete Pythium insidiosum Strain Pi-S, Isolated from a Patient with Pythiosis. Genome Announc. 2015, 3, e00574-15. [CrossRef]

51. Sweredoski, M.J.; Baldi, P. COBEpro: A novel system for predicting continuous B-cell epitopes. Protein Eng. Des. Sel. 2009, 22, 113-120. [CrossRef] [PubMed]

52. Pollastri, G.; Przybylski, D.; Rost, B.; Baldi, P. Improving the prediction of protein secondary structure in three and eight classes using recurrent neural networks and profiles. Proteins 2002, 47, 228-235. [CrossRef]

53. Yao, B.; Zhang, L.; Liang, S.; Zhang, C. SVMTriP: A method to predict antigenic epitopes using support vector machine to integrate tri-peptide similarity and propensity. PLoS ONE 2012, 7, e45152. [CrossRef] [PubMed]

54. Chechi, J.L.; Franckin, T.; Barbosa, L.N.; Alves, F.C.B.; Leite, A.L.; Buzalaf, M.A.R.; dos Santos, L.D.; Bosco, S.M.G. Infering putative virulence factors for Pythium insidiosum by proteomic approach. Med. Mycol. 2019, 57, 92-100. [CrossRef]

55. Wang, J.; Du, X.J.; Lu, X.N.; Wang, S. Immunoproteomic identification of immunogenic proteins in Cronobacter sakazakii strain BAA-894. Appl. Microbiol. Biotechnol. 2013, 97, 2077-2091. [CrossRef]

56. González-Aravena, M.; Calfio, C.; Mercado, L.; Morales-Lange, B.; Bethke, J.; De Lorgeril, J.; Cárdenas, C.A. HSP70 from the Antarctic sea urchin Sterechinus neumayeri: Molecular characterization and expression in response to heat stress. Biol. Res. 2018, 51, 8. [CrossRef]

57. Feder, M.E.; Hofmann, G.E. Heat-shock proteins, molecular chaperones, and the stress response: Evolutionary and Ecological Physiology. Annu. Rev. Physiol. 1999, 61, 243-282. [CrossRef] [PubMed]

58. Kregel, K.C. Heat shock proteins: Modifying factors in physiological stress responses and acquired thermotolerance. J. Appl. Physiol. 2002, 92, 2177-2186. [CrossRef]

59. Tiwari, S.; Thakur, R.; Shankar, J. Role of Heat-Shock Proteins in Cellular Function and in the Biology of Fungi. Biotechnol. Res. Internat. 2015, 2015, 132635. [CrossRef] [PubMed]

60. Ohba, M. A 70-kDa heat shock cognate protein suppresses the defects caused by a proteasome mutation in Saccharomyces cerevisiae. FEBS Lett. 1994, 351, 263-266. [CrossRef] [PubMed]

61. Bisio, L.C.; Silva, S.P.; Pereira, I.S.; Xavier, M.A.S.; Venancio, E.J.; Puccia, R.; Soares, C.M.A.; Felipe, M.S.S. A new Paracoccidioides brasiliensis 70-kDa heat shock protein reacts with sera from paracoccidioidomycosis patients. Med. Mycol. 2005, 43, 495-503. [CrossRef]

62. Keeratijarut, A.; Lohnoo, T.; Rujirawat, T.; Yingyong, W.; Kalambaheti, T.; Miller, S.; Phuntumart, V.; Krajaejun, T. The Immunoreactive Exo-1,3- $\beta$-Glucanase from the Pathogenic Oomycete Pythium insidiosum Is Temperature Regulated and Exhibits Glycoside Hydrolase Activity. PLoS ONE 2015, 10, e0135239. [CrossRef]

63. Garfoot, A.L.; Dearing, K.L.; Vanschoiack, A.D.; Wysocki, V.H.; Rappleye, C.A. Eng1 and Exg8 Are the Major ß-Glucanases Secreted by the Fungal Pathogen Histoplasma capsulatum. J. Biol. Chem. 2017, 292, 4801-4810. [CrossRef]

64. Holbrook, E.D.; Edwards, J.A.; Youseff, B.H.; Rappleye, C.A. Definition of the Extracellular Proteome of Pathogenic-Phase Histoplasma capsulatum. J. Proteome Res. 2011, 10, 1929-1943. [CrossRef]

65. Moreira, A.L.E.; Oliveira, M.A.P.; Silva, L.O.S.; Inácio, M.M.; Bailão, A.M.; Parente-Rocha, J.A.; Cruz-Leite, V.R.M.; Paccez, J.D.; Soares, C.M.A.; Weber, S.S.; et al. Immunoproteomic Approach of Extracellular Antigens from Paracoccidioides Species Reveals Exclusive B-Cell Epitopes. Front. Microbiol. 2020, 10, 2968. [CrossRef] [PubMed]

66. Adams, D.J. Fungal cell wall chitinases and glucanases. Microbiology 2004, 150, 2029-2035. [CrossRef] [PubMed]

67. Smits, G.J.; Van Den Ende, H.; Klis, F.M. Differential regulation of cell wall biogenesis during growth and development in yeast. Microbiology 2001, 147, 781-794. [CrossRef]

68. Fontaine, T.; Hartland, R.P.; Beauvais, A.; Diaquin, M.; Latge, J.P. Purification, characterization of an endo-1,3-betaglucanase from Aspergillus fumigatus. Eur. J. Biochem. 1997, 243, 315-321. [CrossRef]

69. Martin, K.; McDougall, B.M.; Mcllroy, S.; Chen, J.; Seviour, R.J. Biochemistry and molecular biology of exo cellular fungal ß-(1,3)-and B-(1,6)-glucanases. FEMS Microbiol. Rev. 2007, 31, 168-192. [CrossRef] [PubMed] 
70. Labeé, G.; Bezaire, J.; Groot, S.; How, C.; Rasmusson, T.; Yaeck, J.; Jervis, E.; Dmitrienko, G.I.; Guillemette, J.G. High level production of the Magnaporthe grisea fructose 1,6-biphosphate aldolase enzyme in Escherichia coli using a small volume bench-top fermentor. Protein Expr. Purif. 2007, 51, 110-119. [CrossRef]

71. Cooper, S.J.; Leonard, G.A.; McSweeney, S.M.; Thompson, A.W.; Naismith, J.H.; Qamar, S.; Plater, A.; Berry, A.; Hunter, W.N. The crystal structure of a class II fructose-1,6-bisphosphate aldolase shows a novel binuclear metal-binding active site embedded in a familiar fold. Structure 1996, 4, 1303-1315. [CrossRef]

72. Labbé, G.; Groot, S.; Rasmusson, T.; Milojevic, G.; Dmitrienko, G.I.; Guillemette, J.G. Evaluation of four microbial class II fructose 1,6-bisphosphate aldolase enzymes for use as biocatalysts. Protein Expr. Purif. 2011, 80, 224-233. [CrossRef]

73. Han, X.; Zhu, X.; Zhu, S.; Wei, L.; Hong, Z.; Guo, L.; Chen, H.; Chi, B.; Liu, Y.; Feng, L.; et al. A Rational Design, Synthesis, Biological Evaluation and Structure-Activity Relationship Study of Novel Inhibitors against Cyanobacterial Fructose-1,6bisphosphate Aldolase. J. Chem. Inf. Model. 2016, 56, 73-81. [CrossRef]

74. Rodaki, A.; Young, T.; Brown, A.J.P. Effects of Depleting the Essential Central Metabolic Enzyme Fructose-1,6-Bisphosphate Aldolase on the Growth and Viability of Candida albicans: Implications for Antifungal Drug Target Discovery. Eukaryot. Cell 2006, 5, 1371-1377. [CrossRef]

75. Rodrigues, A.M.; Kubitschek-Barreira, P.H.; Pinheiro, B.G.; Teixeira-Ferreira, A.; Hahn, R.C.; Camargo, Z.P. Immunoproteomic analysis reveals novel candidate antigens for the diagnosis of paracoccidioidomycosis due to Paracoccidioides lutzii. J. Fungi 2020, 6, 357. [CrossRef] [PubMed]

76. Tomazett, M.V.; Baeza, L.C.; Paccez, J.D.; Parente-Rocha, J.A.; Ribeiro-Dias, F.; de Almeida Soares, C.M. Identification and characterization of Paracoccidioides lutzii proteins interacting with macrophages. Microbes Infect. 2019, 21, 401-411. [CrossRef] [PubMed]

77. Xin, H.; Dziadek, S.; Bundle, D.R.; Cutler, J.E. Synthetic glycopeptide vaccines combining ß-mannan and peptide epitopes induce protection against candidiasis. Proc. Natl. Acad. Sci. USA 2008, 105, 13526-13531. [CrossRef]

78. Xin, H.; Cutler, J.E. Vaccine and Monoclonal Antibody That Enhance Mouse Resistance to Candidiasis. Clin. Vaccine Immunol. 2011, 18, 1656-1667. [CrossRef]

79. Stie, J.; Bruni, G.; Fox, D. Surface-associated plasminogen binding of Cryptococcus neoformans promotes extracellular matrix invasion. PLoS ONE 2009, 4, e5780. [CrossRef] [PubMed]

80. Chaves, E.G.; Weber, S.S.; Bao, S.N.; Pereira, L.A.; Bailao, A.M.; Borges, C.L.; Soares, C.M. Analysis of Paracoccidioides secreted proteins reveals fructose 1,6-bisphosphate aldolase as a plasminogen-binding protein. BMC Microbiol. 2015, 15, 53. [CrossRef] [PubMed]

81. Dickman, M.B.; Yarden, O. Serine/Threonine Protein Kinases and Phosphatases in Filamentous Fungi. Fungal Genet. Biol. 1999, 26, 99-117. [CrossRef] [PubMed]

82. Miranda, M.N.; Masuda, C.A.; Ferreira-Pereira, A.; Carvajal, E.; Ghislain, M.; Montero-Lomelí, M. The serine/threonine protein phosphatase Sit4p activates multidrug resistance in Saccharomyces cerevisiae. FEMS Yeast Res. 2010, 10, 674-686. [CrossRef]

83. Leiter, É.; González, A.; Erdei, É.; Casado, C.; Kovács, L.; Ádám, C.; Oláh, J.; Miskei, M.; Molnar, M.; Farkas, I.; et al. Protein phosphatase Z modulates oxidative stress response in fungi. Fungal Genet. Biol. 2012, 49, 708-716. [CrossRef]

84. Muszkieta, L.; Carrion, S.J.; Robinet, P.; Beau, R.; Elbim, C.; Pearlman, E.; Latgé, J.P. The protein phosphatase PhzA of A. fumigatus is involved in oxidative stress tolerance and fungal virulence. Fungal Genet. Biol. 2014, 66, 79-85. [CrossRef]

85. Szabó, K.; Jakab, Á.; Póliska, S.; Petrényi, K.; Kovács, K.; Issa, L.H.B.; Emri, T.; Pócsi, I.; Dombrádi, V. Deletion of the fungus specific protein phosphatase Z1 exaggerates the oxidative stress response in Candida albicans. BMC Genom. 2019, 20, 873. [CrossRef]

86. Dantas, A.S.; Day, A.; Ikeh, M.; Kos, I.; Achan, B.; Quinn, J. Oxidative stress responses in the human fungal pathogen, Candida albicans. Biomolecules 2015, 5, 142-165. [CrossRef]

87. Brito, W.A.; Rezende, T.C.V.; Parente, A.F.; Ricart, C.A.O.; Sousa, M.V.; Báo, S.N.; Soares, C.M.A. Identification, characterization and regulation studies of the aconitase of Paracoccidioides brasiliensis. Fungal Biol. 2011, 115, 697-707. [CrossRef]

88. Narahari, J.; Ma, R.; Wang, M.; Walden, W.E. The aconitase function of iron regulatory protein 1. Genetic studies in yeast implicate its role in iron-mediated redox regulation. J. Biol. Chem. 2000, 275, 16227-16234. [CrossRef]

89. Villafranca, J.J.; Mildvan, A.S. The mechanism of aconitase action. Detection and properties of enzyme-metal-substrate and enzyme-metal-inhibitor bridge complexes with manganese (II) and iron (II). J. Biol. Chem. 1972, 247, 3454-3463. [CrossRef]

90. Lian, T.; Simmer, M.I.; D’Souza, C.A.; Steen, B.R.; Zuyderduyn, S.D.; Jones, S.J.; Marra, M.A.; Kronstad, J.W. Iron-regulated transcription and capsule formation in the fungal pathogen Cryptococcus neoformans. Mol. Microbiol. 2005, 55, 1452-1472. [CrossRef]

91. Almirón, M.; Martínez, M.; Sanjuan, N.; Ugalde, R.A. Ferrochelatase is present in Brucella abortus and is critical for its intracellular survival and virulence. Infect. Immun. 2001, 69, 6225-6230. [CrossRef]

92. Ibrahim, A.S. Host cell invasion in mucormycosis: Role of iron. Curr. Opin. Microbiol. 2011, 14, 406-411. [CrossRef] [PubMed]

93. Schaible, U.E.; Kaufmann, S.H.E. Iron and microbial infection. Nat. Rev. Microbiol. 2004, 2, 946-953. [CrossRef]

94. Krajaejun, T.; Khositnithikul, R.; Lerksuthirat, T.; Lowhnoo, T.; Rujirawat, T.; Petchthong, T.; Yingyong, W.; Suriyaphol, P.; Smittipat, N.; Juthayothin, T.; et al. Expressed sequence tags reveal genetic diversity and putative virulence factors of the pathogenic oomycete Pythium insidiosum. Fungal Biol. 2011, 115, 683-696. [CrossRef]

95. Santurio, J.M.; Zanette, R.A.; Bitencourt, P.E.R.; Alves, S.H.; Fighera, R.A.; Flores, M.M.; Wolkmer, P.; Hecktheuer, P.A.; Thomas, L.R.; Pereira, P.L.; et al. Insights into the pathophysiology of iron metabolism in Pythium insidiosum infections. Vet. Microbiol. 2013, 162, 826-830. [CrossRef] 
96. Lozano-Durán, R.; Robatzek, S. 14-3-3 Proteins in Plant-Pathogen Interactions. Mol. Plant-Microbe Interact. 2015, 28, 511518. [CrossRef]

97. Gardino, A.K.; Yaffe, M.B. 14-3-3 proteins as signaling integration points for cell cycle control and apoptosis. Semin. Cell. Dev. Biol. 2011, 22, 688-695. [CrossRef] [PubMed]

98. Obsilova, V.; Kopecka, M.; Kosek, D.; Kacirova, M.; Kylarova, S.; Rezabkova, L.; Obsil, T. Mechanisms of the 14-3-3 protein function: Regulation of protein function through conformational modulation. Physiol. Res. 2014, 63, 155-164. [CrossRef] [PubMed]

99. Kafle, A.; Puchadapirom, P.; Plumworasawat, S.; Dontumprai, R.; Chan-On, W.; Buates, S.; Laha, T.; Sripa, B.; Suttiprapa, S. Identification and characterization of protein 14-3-3 in carcinogenic liver fluke Opisthorchis viverrini. Parasitol. Int. 2017, 66, 426-431. [CrossRef]

100. Andreotti, P.F.; Monteiro da Silva, J.L.; Bailão, A.M.; Soares, C.M.; Benard, G.; Soares, C.P.; Mendes-Giannini, M.J. Isolation and partial characterization of a $30 \mathrm{kDa}$ adhesin from Paracoccidioides brasiliensis. Microbes Infect. 2005, 7, 875-881. [CrossRef]

101. Marcos, C.M.; Silva, J.F.; Oliveira, H.C.; Assato, P.A.; Singulani, J.L.; Lopez, A.M.; Tamayo, D.P.; Hernandez-Ruiz, O.; McEwen, J.G.; Mendes-Giannini, M.J.; et al. Decreased expression of 14-3-3 in Paracoccidioides brasiliensis confirms its involvement in fungal pathogenesis. Virulence 2016, 7, 72-84. [CrossRef]

102. Marcos, C.M.; Oliveira, H.C.; Assato, P.A.; Andrade, C.R.; Fusco-Almeida, A.M.; Mendes-Giannini, M.J.S. Paracoccidioides brasiliensis 14-3-3 protein is important for virulence in a murine model. Med. Mycol. 2018, 57, 900-904. [CrossRef]

103. Scorzoni, L.; de Paula e Silva, A.C.A.; Oliveira, H.C.; Santos, C.T.; Singulani, J.L.; Assato, P.A.; Marcos, C.M.; Oliveira, L.T.; Fregonezi, N.F.; Rossi, D.C.P.; et al. In Vitro and In Vivo Effect of Peptides Derived from 14-3-3 Paracoccidioides spp. Protein. J. Fungi 2021, 7, 52. [CrossRef]

104. Champer, J.; Ito, J.I.; Clemons, K.V.; Stevens, D.A.; Kalkum, M. Proteomic Analysis of Pathogenic Fungi Reveals Highly Expressed Conserved Cell Wall Proteins. J. Fungi 2016, 2, 6. [CrossRef] [PubMed] 